\title{
Finding and Testing Ant Assemblages as Indicators of Recovery Successions in Coal- Affected Areas
}

\author{
Svetlana Blinova ${ }^{1, *}$, Sergey Luzyanin ${ }^{1}$, and Tatiana Dobrydina ${ }^{2}$ \\ ${ }^{1}$ Kemerovo State University, Department of Ecology and Nature Management, 650000, 6 Krasnaya \\ st., Kemerovo, Russian Federation \\ ${ }^{2}$ Kemerovo State University, Department of Foreign Languages in Professional Communication, \\ 650000, 6 Krasnaya st., Kemerovo, Russian Federation
}

\begin{abstract}
We studied the species richness of ants and types of nests on dumps of different ages formed by waste from the coal mining industry in the taiga and forest-steppe zones of Kemerovo Region, the Russian Federation. It was revealed that only underground nests of L. niger, the prevalence of species with a wide ecological valence, which belong to the ubiquist group, and groups of species with an adaptive type of response to anthropogenic pressure, act as indicators of initial successions. It was revealed that the following indicators act as indicators of the initial successions: the presence of only underground nests of L. niger, the predominance of species with a wide ecological valence (ubiquist) and species with an adaptive type of response to anthropogenic pressure.
\end{abstract}

\section{Introduction}

The study of the bioindication capabilities of living things is one of the current issues. The search for such objects is a topical research in connection with the increase in anthropogenic pressure, on the one hand, and the need to track demutational processes, i.e. the processes of ecosystem restoration to the state close to the initial one, on the other hand. The importance of these studies is especially obvious on the territory of Kemerovo Region (Russia), where more than $4 \%$ of the entire territory is now subject to anthropogenic transformation due to the extraction of coal by open and underground methods. At the same time, the ratio of the area of disturbed lands to the total area occupied by dumps is approximately $85 \%$ and $15 \%$, respectively. Every year, 2.0-2.5 thousand hectares are allotted for the extraction of minerals [1]. In general, in Russia from 2011 to 2018, coal production increased from 336.7 to 439.3 million tons. Open mining gives the maximum production of coal; and more than $60 \%$ is Kuzbass coal [2].

According to the existing regulations, each coal mining enterprise is obliged to carry out reclamation measures. Obviously, reclamation accelerates the formation of diverse and

\footnotetext{
* Corresponding author: $\underline{\text { sv blinova@mail.ru }}$
} 
complex plant communities that positively affect the diversity of different groups of invertebrates, such as spiders [3], ground beetles (Carabidae), centipedes (Chilopoda), millipedes (Diplopoda) [4], etc. At the same time, there are studies showing that the succession also proceeds swimmingly in non-reclaimed areas. In such areas, restoration occurs mainly due to rare species [4].

Ants have a quick response to environmental changes and a relatively constant habitat, therefore they are a convenient object for bioindication. The results obtained by the group of authors [5] indicate that the abundance and species richness of ants are considered to be suitable indicators of changes in abiotic conditions, as well as functional indicators of an important ecosystem process.

As shown by the example of the northern parts of Egypt, species diversity changes with changes in living conditions as a result of urbanization and agriculture [6]. In Italy, depending on the age of the dumps, the species richness of individual genera changes, the number of cryophiles and forest species changes [7].

J.H. Bihn, G. Gebauer, R. Brandl [8] found a strong correlation between species and functional diversity, regardless of the functional traits used. Moreover, the restoration of ant assemblage in tropical secondary forests along the successional gradient was primarily due to rare species that are functionally unique.

In addition, using the example of the riparian Neotropical ecosystems, it was revealed that the soil structure determines the settlement of ants of different size classes. Thus, the predominance of small structural soil units contributes to the predominance of small species of ants, up to $5 \mathrm{~mm}$ in body length. This indicator is proposed to be used as a theoretically grounded quantitative approach in bioindication [9].

In general, bioindicators make it possible to assess the state of the environment quickly. However, ants often show species-specific or regional characteristics in response to different anthropogenic factors. Therefore, the purpose of this work is to assess the demutation processes in anthropogenically transformed, coal-affected areas using ant assemblage.

\section{Materials and Methods}

All the material was collected on the territory of Kemerovo Region, the Russian Federation, in 2000-2019, situated in the forest-steppe and forest zones of the temperate climate of the Palaearctic. The studied areas are located on the dumps of coal mining enterprises - two open mines (open mining) and a mine (underground mining).

All ant assemblage studies were performed with the usage of standard methods. The study of the species composition and population density of ants was carried out in the areas formed at different times. At each site, 10 test plots were laid with dimensions of $10 \mathrm{~m} \times 10 \mathrm{~m}$. A detailed description of the surveyed areas is given in the articles [10-11].

During the field collection of the materials, the projective cover of the site (the area occupied by plants, in percent), and the type of ant nests were recorded. In addition, according to the literature and our own data, we have established preferred habitats, i.e. a plant community where this species of ants is more often found in natural habitat.

The analysis of the vertical structure of ant assemblage was carried out based on the classification proposed by Anatoly A. Zakharov [12].

Ants were identified under stationary conditions according to W. Czechowski, A. Radchenko, W. Czechowska [13]. Since the species Tetramorium caespitum complex are difficult to distinguish, we considered them as Tetramorium caespitum sensu lato (s.1.).

All the obtained material was processed statistically in Microsoft Excel. 


\section{Results and Discussion}

The studies carried out in 2000-2019 made it possible to identify 17 ant species belonging to 5 genera of two subfamilies of the Formicidae (Hymenoptera) in Kemerovo Region (Russia). The obtained results indicate that the settlement of ants on new territories, such as the studied dumps, is influenced by a significant number of factors. Moreover, each of the factors can be self-sufficient.

We proceed from the statement [14] that the existence and, therefore, the settlement of ants is possible only if there is a free suitable ecological niche. This primarily depends on the type and location of the nest and food preferences.

We consider the analysis of biomorphs as one of the aspects of the study of food preferences. All the species of ants we have found are cryophiles-zoophages. The exception is Lasius flavus, a geophiles. However, the registered representatives of 5 genera (Myrmica Latr., Tetramorium Mayr., Camponotus Mayr., Formica L., Lasius Fabr.) belong to different size classes, which expands the ability of different ant species to inhabit the same ecosystem. Thus, this factor does not significantly affect the distribution of species in the studied succession series.

The analysis of the vertical structure showed a strong relationship between the projective cover, crown density, and the species composition of ant assemblage.

On the contrary, we noted 5 types of ant nests (Table 1): underground (U), underground and dead wool (UW), with an earthen mound (EM), underground with plant material at the entrances (UP), with a plant dome (D). It should be noted that two types of nests have been identified for L. niger: underground and with an earthen mound. This is the only species whose nest type and height depend on the age of the dump $(r=0.984$ at $p<0.05)$ : only underground nests are recorded on young dumps less than 10 years old. With increasing the age of the dump, the height of the earthen mound also increases. Only for this species, a strong relationship $(\mathrm{r}=0.986$ at $\mathrm{p}<0.05)$ was noted between the projective cover of the site and the height of the ground part of the nest. For the rest of the types, no reliable relationship was found. We believe that this is a promising indicator for biomonitoring research.

The type of nest in F. sanguinea depends on the helper species, since this species is an optional slave owner.

To understand the possibility of settling on the studied dumps, we identified 4 groups of preferred habitats for the discovered ant species: ubiquist - species found in many types of vegetation; the remaining groups are named according to the prevailing type of vegetation, respectively, meadow-forest, forest and meadow-steppe species (Table 1).

Table 1. The species composition of ants on the coal waste dumps and some of their characteristics (abbreviations are in the text).

\begin{tabular}{|c|c|c|c|}
\hline Species & $\begin{array}{c}\text { Main } \\
\text { type of } \\
\text { nest }\end{array}$ & $\begin{array}{c}\text { Preferred } \\
\text { habitats }\end{array}$ & $\begin{array}{c}\text { Type of } \\
\text { behavior } \\
\text { reaction }\end{array}$ \\
\hline 1. Myrmica rubra (L.) & $\mathrm{U}$ & meadow-forest & $\mathrm{N}$ \\
\hline 2. M. ruginodis Nyl. & $\mathrm{UW}$ & forest & $\mathrm{N}$ \\
\hline 3. M. scabrinodis Nyl. & $\mathrm{EM}$ & meadow-forest & $\mathrm{Q}$ \\
\hline 4. M. schencki Vier. & $\mathrm{EM}$ & meadow-forest & $\mathrm{Q}$ \\
\hline 5. Tetramorium caespitum s.l. & $\mathrm{EM}$ & meadow-steppe & $\mathrm{A}$ \\
\hline
\end{tabular}




\begin{tabular}{|c|c|c|c|}
\hline 6. Camponotus saxatilis Ruzs. & $\mathrm{U}$ & ubiquist & $\mathrm{Nm}$ \\
\hline $\begin{array}{l}\text { Subgenus Raptifotmica Forel } \\
\text { 7. Formica sanguinea Latr. }\end{array}$ & $\mathrm{D}, \mathrm{U}$ & forest & $\mathrm{N}$ \\
\hline \multicolumn{4}{|l|}{ Subgenus Serviformica Forel } \\
\hline 8. F. cunicularia Latr. & UP & forest & Q \\
\hline 9. F. fusca L. & EM & ubiquist & $\mathrm{Q}$ \\
\hline 10. F. rufibarbis Fabr. & UP & meadow-steppe & Q \\
\hline \multicolumn{4}{|l|}{ Subgenus Formica s. str. (L.) } \\
\hline 11. F. aquilonia Yarr. & $\mathrm{D}$ & forest & $\mathrm{N}$ \\
\hline 12. F. lugubris Zett. & $\mathrm{D}$ & forest & $\mathrm{N}$ \\
\hline 13. F. pratensis Retz. & $\mathrm{D}$ & meadow-forest & Q \\
\hline 14. F. rufa L. & $\mathrm{D}$ & meadow-forest & Q \\
\hline 15. Lasius flavus $\mathrm{F}$. & EM & ubiquist & $\mathrm{Nm}$ \\
\hline 16. L. niger (L.) & $\mathrm{U}, \mathrm{EM}$ & ubiquist & A \\
\hline 17. L. platythorax Seifert & EM & forest & A \\
\hline
\end{tabular}

Our hypothesis is that the species change when settling the dumps, starting with the ubiquist species and the most xerophilic groups (meadow-steppe species) gradually; as the projective cover increases and the forest vegetation appears, the meadow-forest and forest species settle the dumps. In support of the hypothesis, it was revealed that in the succession row of dumps, with the age of the latter, the projective cover area increases $(r=0.98$ at $p$ $<0.05$ ). This gradually creates conditions for the existence of the meadow-forest and forest species. The correlation analysis shows that this pattern has a positive trend $(\mathrm{r}=0.501$ at $\mathrm{p}$ $<0.05$ ), however, L. niger umbrophil nests make up a significant proportion (up to $10-30 \%$ of the number of nests) in the control. At the same time, the number of F. sanguinea nests cannot be calculated using similar methods, since this species is an optional slave owner, and it builds a nest only with an auxiliary species, for example, F. fusca.

Therefore, this indicator can be considered as a bioindication one, but the analysis should take into account only the qualitative composition of ant assemblage.

However, as shown by Preston H. Brown et al. [15] on the example of urbanized areas of Puerto Rico, species with a wide ecological valence are the first to settle during the recovery succession. In contrast, the ant species noted in older sites are more specialized. Our studies confirm this: the ratio of the ubiquists to the forest group changes in favour of the latter with an increase in the age of the dump $(\mathrm{r}=0.56$ at $\mathrm{p}<0.05)$. A positive tendency $(\mathrm{r}=0.61$ at $\mathrm{p}$ $<0.05)$ between the type of formed nests and ecological valence is similarly expressed: underground nests are characteristic of ubiquists and xerophilic groups.

In general, in relation to the pollution and the rate of new sites' settlement, four types of ant behavior reaction can be distinguished:

Adaptive (A): this type includes species of ants that can withstand a high anthropogenic load. They are the first to settle on the formed dumps of coal enterprises, with a low or 
complete absence of projective cover. The characteristic 'urbophilic species' is applicable for them, i.e. species that tend to settle on the areas with a high degree of anthropogenic impact. Often, in the absence of competition, it is these species that are abundant in the most polluted or newly formed areas. Over time, the number of such species usually decreases. First of all, the species belonging to the genus Lasius: L. niger, L. platythorax and Tetramorium caespitum s. 1. are classified as this type.

Quasi-adaptive (Q): this type of reaction includes the species, the number of which is maximum in the "middle" period while at the initial stages of succession it is low. Approximately, by 25-30 years of the existence of the dump, the number of nests of these species becomes significant. Further, the density of settlements of these species gradually decreases, reaching the minimum values in the control zone.

First, this group includes the species belonging to the genus Formica, Subgenus Serviformica (F. fusca, F. cunicularia, F. rufibarbis) and species of the genus Myrmica (M. scabrinodis, M. schencki). Probably, the species classified to this group cannot compete with the later appearing Formica s. str. During subsequent recovery processes, first, they decrease the number, and then disappear. According to the observations of H. Gibb [16], competitive relations in ant assemblages of boreal forests of boreal forests play a significant role in the study of successions. The author showed that the dominant species of red wood ants (Formica aquilonia) reduce the number of other ant species. And when the dominants are removed, the number of other species increases, which is consistent with our observations. However, using the example of boreal forest northern Sweden, it is shown that in the habitat of Formica aquilonia, on the contrary, species of the genus Myrmica may be more abundant [17]. Separately, it is necessary to highlight two species of ants related to red wood ants Formica s. str. (F. rufa, F. pratensis). They are light-loving and thermophilic species, in contrast to the rest of the noted Formica s. str. Therefore, in our opinion, they settle on dumps as soon as the food supply allows. Thus, we observed an anthill F. rufa up to $70 \mathrm{~cm}$ in height on reclaimed sites about 30 years old with separately growing birches (Betula pendula).

Non-adaptive $(\mathrm{N})$ : species of ants, the number of which decreases with an increase in the degree of pollution or deformation of the biocenosis. On the dumps formed by the waste of the coal industry and passed the technical and biological stages of reclamation, these species are one of the last to settle. So, in the ongoing succession on the mine dumps, the anthills red wood ants Formica s. str. (F. aquilonia, F. lugubris) appear only with the formation of the tree layer no earlier than 20 years. It is for these species that a positive trend was revealed between an increase in the projective cover of the vegetation cover and the density of nests (in general, $\mathrm{r}<0.51$ at $\mathrm{p}<0.05$ ). This group also includes the facultative parasite $\mathrm{F}$. sanguinea, whose winged individuals were observed on newly formed dumps. However, we registered the nests only in the control, where populations of potential slave species settle. In our case, these can be F. fusca, F. cunicularia, F. rufibarbis.

It is interesting to note, according to our research, Myrmica rubra, in general, an urbanophilic species, tend to areas subject to anthropogenic impact. In the most polluted zone (near the sources of technogenic pollution), other species of this genus have not been found. In natural cenoses, the density of M. rubra nests is minimal. However, ants of this genus are not found in areas prone to pollution by solid industrial waste, including coal dust. At the same time, nests of Myrmica rubra were recorded only in natural cenoses on dumps formed as a result of brown coal mining in the Czech Republic [7]. Such differences may be due to the difference in climatic conditions, species richness and, accordingly, interspecific competition. Therefore, considering the species in the context of the restorative succession on the dumps of coal enterprises, we classify this species as non-nadaptive species under the influence of the coal mining industry. 
M. ruginodis is a forest species inhabiting the Kemerovo Region conditions mainly in the taiga zone. Therefore, like the previous species, it populates the dumps of coal enterprises in the last turn, only after the formed tree layer, mainly in mixed coniferous-deciduous forests.

No marked behavior $(\mathrm{Nm})$ : a rare type of ants' behavior reaction, which implies practically unchanged indicators of the density of nests, regardless of the degree of anthropogenic impact. These species, in our conditions, either live underground (for example, Lasius flavus), or settle underground (Camponotus saxatilis). At the same time, the first species is found in almost all areas studied, while the second one is recorded only in the forest-steppe zone.

\section{Conclusion}

The studies and data analysis showed that some of the parameters of ant assemblage can be considered as indicators of recovery processes on coal waste dumps. Thus, the presence of only underground nests of L. niger in the studied areas can be considered one of the indicators of the first stages of succession; the height of the earthen mound is a marker of the "old" dump with the age of at least 30 years.

For forest and forest-steppe zones, the ratio of groups of preferred habitats can be used as a marker. The prevalence of ubiquist indicates the initial stage of succession.

The changing ratio of the number of ant groups of the adaptive and non-adaptive types, in our opinion, is the most accurate indicator of the course of the restorative succession of dumps of coal mining enterprises.

However, it is possible that in other climatic zones or plant communities species may behave reaction differently. Therefore, we do not exclude that further research may reveal additional trends and bioindicators.

\section{References}

1. K. Tomilin, A. Kharitonov, N. Bondarev E3S Web Conf. 174, 02032 (2020)

2. T. Galanina, T. Koroleva, L. Zakamskaya, I. Tretyakova, E3S Web of Conf. 174, 02017 (2020)

3. L. Trilikauskas, S. Luzyanin, E3S Web Conf. 41, 02021 (2018)

4. R. Tropek, T. Kadlec, P. Karesova, L. Spitzer, P. Kocarek, I. Malenovsky, P. Banar, I. H. Tuf, M. Hejda, M. Konvicka, Journal of Applied Ecology, 47(1), 139-147 (2010)

5. Y. Tiedea, J. Schlautmanna, D. A. Donoso, Ch. I. B. Wallis, J. Bendix, R. Brandl, N. Farwig, Ecol. Indic. 83, 527-537 (2017)

6. M. M. El Bokl, F. M. Semida, M. S. Abdel-Dayem, E.I. El, Int. J. Entomol. Res. 03(02), 35-46 (2015)

7. L. Ottonetti, L. Tucci, G. Santini, Restoration Ecology, 14, 1, 60-66 (2006)

8. J.H. Bihn, G. Gebauer, R. Brandl, Ecology, 91, 782-792 (2010)

9. C.B. da Costa-Milanez, J.D. Majer, P. de Tarso Amorim Castro, S.P. Ribeiro Perspectives in Ecology and Conservation, 15, 2, 102-108 (2017)

10. S. Blinova, S. Luzyanin, T. Dobrydina, E3S Web of Conf. 174, 02016 (2020)

11. S. Blinova, T. Dobrydina, E3S Web of Conf. 21, 02011 (2017)

12. A. A. Zakharov, Memorabilia Zool. 44, 7-11 (1990) 
13. W. Czechowski, A. Radchenko, W. Czechowska, The ants (Hymenoptera, Formicidae) of Poland (MIZ, Polish Academy of Sciences, Warszawa, 2002)

14. Ants: standard methods for measuring and monitoring biodiveraity (Washington, DC. Smithsonian Institution Press, 2000)

15. P.H. Brown, D.M. Miller, C.C. Brewster, R.D. Fell, Urban Ecosystems, 16(2), 175-192 (2013)

16. H. Gibb, Ecology, 92(10), 1871-1878 (2011)

17. O. Alinvi, J. Bohlin, J. P. Ball, Insectes Sociaux, 55, 1-11 (2008) 